16. Pro publichni zakupivli [Electronic resource]: Law of Ukraine from 25.12.2015 No. 922. - Available at: \www/URL: http:// zakon2.rada.gov.ua/laws/show/922-19

17. Pro elektronnu komertsiiu [Electronic resource]: Law of Ukraine from 03.09.2015 No. 675-VIII. - Available at: \www/URL: http://zakon2.rada.gov.ua/laws/show/675-19

18. Pro elektronni dokumenty ta elektronnyi dokumentoobih [Electronic resource]: Law of Ukraine from 22.05.2003 No. 851-IV. Available at: \www/URL: http://zakon4.rada.gov.ua/laws/show/ $851-15$

19. Pro elektronnyi tsyfrovyi pidpys [Electronic resource]: Law of Ukraine from 22.05.2003 No. 852-IV. - Available at: \www/ URL: http://zakon2.rada.gov.ua/laws/show/852-15

20. Pro zatverdzhennia form dokumentiv u sferi publichnykh zakupivel [Electronic resource]: Order of the Ministry of Economic Development and Trade of Ukraine from 22.03.2016 No. 490. - Available at: \www/URL: http://zakon3.rada.gov.ua/ laws/show/z0449-16

21. Official website of the ProZorro [Electronic resource]. - 2016. Available at: \www/URL: https://prozorro.gov.ua/

22. KPI [Electronic resource] // ProZorro ExplorerEN. - 2016. Available at: \www/URL: http://bi.prozorro.org/sense/app/ e1a87316-d81e-4142-bd2b-5f2cae95b136/sheet/HEjZR/state/ analysis

23. Interpayp Ukrayina, TOV [Electronic resource] // BusinessGuide. - 2016. - Available at: \www/URL: http://interpipe. business-guide.com.ua/

24. Official website of the National Joint-Stock Company «Naftogaz of Ukraine» [Electronic resource]. - 2016. - Available at: \www/ URL: http://www.naftogaz.com/www/3/nakweben.nsf

25. Official website of the PJSC » Kyivenergo» [Electronic resource]. 2016. - Available at: \www/URL: http://kyivenergo.ua/

\section{РАЗВИТИЕ ДИАГНОСТИКИ ЛРЕДПРИЯТИЯ В СИСТЕМЕ} ЗЛЕКТРОННЫХ ПУБЛИЧНЫХ ЗАКУПОК НА ОСКОВЕ ЛОГИСТИКИ

Раскрыто содержание понятия «информационно-финансовые потоки» и представлены концептуальные основы диагностики предприятия в системе электронных публичных закупок на основе логистики. Проанализирован процесс осуществления электронных публичных закупок в аспекте информационнофинансовой, информационной, финансовой логистики, документологистики, логистики товаров, услуг, работ. Предложена система показателей функционирования системы электронных публичных закупок на основе логистического подхода на макрои микроуровнях.

ключевые слова: электронные публичные закупки, логистика, информационно-финансовые потоки, система «информация - ресурс - время».

Klyuvak Oksana, PhD, Lecturer, Department of Business Economy and Information Technology, Private Higher Educational Institution «Lviv University of Business and Law», Ukraine, e-mail: oksana_klyuvak@ukr.net, ORCID: http://orcid.org/00000003-3383-926X

Skrynkovskyy Ruslan, PhD, Associate Professor, Department of Business Economy and Information Technology, Private Higher Educational Institution «Lviv University of Business and Law», Ukraine, e-mail: uan lviv@ukr.net, ORCID: http://orcid.org/00000002-2180-8055

\section{Lesko 0., Prychepa I., Lesko T.}

\title{
DEVELOPMENT OF APPROACH TO ANTICIPATORY RISK MANAGEMENT OF THE ENTERPRISE UNDER UNCERTAINTY CONDITIONS
}

Запропоновано комплексний підхід до антисипативного управління ризиками підприємства за умов невизначеності. Підхід грунтується на ранній діагностиці слабких сигналів потенційних можливостей $i$ загроз середовища функиіонування підприємства, що дозволяє прогнозувати їх майбутній розвиток і приймати відповідні превентивні заходи щодо мінімізацій впливу ризиків та використання можливостей для перспективного розвитку підприємства.

Ключові слова: антисипативне управління ризиками, ідентифікащія слабких сигналів, превентивні заходи, оптимізація допустимих ризиків.

\section{Introduction}

Risk management in a period of rapid changes is one of the most important tasks for business entities. In modern conditions, domestic enterprises face complex contradictions and serious challenges to the European and global markets: the level of uncertainty, risks, threats and losses increase, and are intensified by socio-economic and political instability in the country. At the same time, eliminating foreign trade barriers opens new opportunities for economic entities to economic growth, formation and strengthening of their competitive positions, implementation of effective and successful reforms in the national economic system. How successfully and successfully economic entities take advantage of opportunities, minimizing possible risks and losses, depends on the validity and weightedness of strategic benchmarks in business activities and approaches to managing relevant risks in diversified global and European markets.

\section{The object of research and its technological audit}

The object of research is risk management of the enterprise under uncertainty conditions. 
It is worth noting that the problems of risk, having long-standing roots, are not new to society and business. Risky situations can arise in any sphere of a person's life, the functioning and development of organization and causes increased attention to the problems of risks. At the same time, modern business conditions are quite dynamic and unpredictable, which requires the constant attention of enterprises to changes and to take into account the ever new requirements of a highly competitive market environment.

In conditions of globalization and eurointegration, competition has become a global phenomenon and the competitiveness of an enterprise must meet the requirements of the global market, and therefore - be formed on a qualitative basis and be based on new approaches to solving complex problems. This, in turn, does not allow avoiding risks, because any innovation carries a certain level of novelty, increases the uncertainty and unpredictability of the future, the need to develop and implement effective risk management mechanisms increases.

World practice has developed a number of standards, but they are generalized and provide only recommendations for managing business risks, without taking into account the characteristics of the national economic system. The most famous of them are the Australian-New Zealand risk management standard AS/NZS 4360, the Risk Management Standard for the Federation of European Risk Management Associations, the documents of the Basel Committee, Basel-2 capital adequacy standard and the management standards for credit, financial and operating risks, etc. [1].

The processes of globalization and European integration are becoming sources of new risks and only increase uncertainty causes the need to search for effective approaches to managing them. The issues of reducing the uncertainty of the external environment management, early diagnosis of risky situations and the adoption of adequate solutions to minimize the impact of threats and use opportunities for enterprise development are still problematic. An effective risk management system in an unstable economic situation and increasing uncertainty becomes an important tool for ensuring the competitiveness and development of the enterprise in modern economic conditions.

\section{The aim and objectives of research}

The aim of research is development of an integrated approach to enterprise risk management based on the principles of anticipatory management.

To achieve this aim, the following tasks are defined:

1. To analyze the cause-effect relationship between risk and uncertainty.

2. To reveal the main principles of risk management at the enterprise in modern conditions.

3. To describe the main principles of anticipatory management of the enterprise.

4. To develop an integrated approach to the enterprise's risk management in the face of uncertainty.

\section{Research of existing solutions of the problem}

The study of danger, threats and risks have a long history and attracted the attention of humanity long ago. Changing approaches to understanding risks is closely connected with the world view of society in a separate historical epoch, methods of cognition and reflects the person's attitude to the future, to the possibilities of influencing him from the absolute independence of the future from man (everything is decided by the will of the gods) until the appearance of responsibility for his actions (the future is determined by behavior of the person, the accepted decisions and corresponding actions).

With the emergence and development of the market economy, various risk theories began to appear, the main ones of which were discovered in [2-8]. As a science, the theory of risks was formed at the end of the 20th century. Due to the practical need to ensure a stable socio-economic development of society, deepening its importance and became the leading theory in the scientific research of the XXI century.

A great contribution to the formation of modern theory and practice of risk management was carried out by both domestic and foreign researchers. A considerable number of scientific works are devoted to the study of the essence and content of the risk concept, its relation to the concepts of uncertainty, danger and threats [9-13]. The author [9] investigates the historical genesis of the notion of «risk» and summarized many existing approaches to understanding the essence and content of the risk concept, drawing the conclusion that most often the term «risk» is understood as an element of uncertainty of economic operations, the danger of obtaining a negative result and indicate its probabilistic character. Common features and differences in understanding the content of risks, threats and hazards in management activities are generalized in [11-13].

A lot of scientific developments are devoted to problems of understanding the essence of risk management and the formation of a risk management system in the enterprise [1,14-20]. The analysis showed that the most common approach is to understand risk management as a risk management system and economic, more precisely, financial relationships that arise in the management process [14]. Considerable attention in scientific research is given to conceptual approaches to the formation of an effective system of enterprise risk management. [15] points to the need for an integrated approach to enterprise risk management in modern conditions, thereby acquiring a comprehensive character and coordinating throughout the organization. Some researchers [16-18] emphasize the need for direct and reverse linkages between the stages of risk management in order to control and correct this process. In [19], existence of the problem of choosing the most appropriate solution is presented, which is due to the existence of various directions and methods for regulating the risk degree. The author notes that the best option for choosing the direction of risk optimization is a sound combination of several methods, and the main criterion of choice is the availability of an optimal ratio between the achieved degree of risk reduction and the costs necessary for this.

The study of preventive approaches to enterprise management is under the scrutiny of both foreign and domestic researchers [21-26]. In the scientific paper [21], perspective-oriented management of complex economic systems is characterized and a comprehensive approach to realizing this type of management in practice was proposed. The author points out the need for early detection of possible threats by means of investigating the internal and external environment for the search for weak signals, which is the basis for anticipatory management in general. 
The importance of systematic anticipatory management with the use of modern approaches and methods for making managerial decisions was noted in [22]. It is this approach to management that provides economic agents with competitive advantages in modern dynamic conditions of operation.

In work [23] it is noted that the task of anticipatory management is not only the identification of opportunities and threats in the enterprise's management environment, but also, and not least, the ability of the enterprise to take advantage of these opportunities.

A rather complex and time-consuming task is the identification of weak signals in the external environment of the enterprise's management. To address these problems, the groupings of weak signals by types of activity of the enterprise are carried out in [24], it enables managers and specialists of the relevant thematic structural units to identify potential opportunities and threats in the early stages of their specific work in order to make management decisions to anticipate the onset of potential phenomena.

It is important to choose a methodical approach to the company's anticipatory management. The method of perspective diagnostics of weak signals by types of enterprise activity aimed at identification, processing and rating order of weak signals, the interpretation of further development of priority weak signals to specific phenomena and the probabilistic evaluation of the influence of certain events behind weak signals on the performance of a particular species of enterprise activity.

A sufficiently thorough generalization of the theoretical and methodological foundations of anticipatory management is carried out by a group of researchers for machine-building enterprises [26]. They develop theoretical-methodological and methodological-applied basis of anticipatory management of machine-building enterprises on the basis of weak signals. The essence-functional content of anticipatory management is revealed, its specific properties are reflected and weak signals of the environment of functioning are characterized as an information basis for the implementation of this type of management.

Despite certain achievements in the issues of risk assessment and anticipatory management of enterprises, the problem remains to harmonize the interaction of enterprise risk management and preventive risk management under uncertainty conditions. This task can be achieved precisely by means of anticipatory management in the system of risk management of a modern enterprise, which requires further study and deepening of these studies.

\section{Methods of research}

To solve the problems posed in the work, the following methods are used: critical analysis and synthesis, induction and deduction, logical generalization, comparison.

The theoretical basis of research has become the foundations of the use of eco-science in the sphere of managing risk and anticipatory management of enterprises.

\section{Research results}

Multifaceted nature of the risk concept can manifest itself in socio-historical, economic, psychological, legal, political, philosophical, natural and other aspects. The variety of manifestations and the increase in the scale of risks, accompanied by increased uncertainty and unpredictability of the factors of influence, underscore the importance of their study and require the formation of a risk management system at enterprises, taking into account modern management requirements.

Historically, risk is a person's awareness of a certain level (the likelihood of an offensive) of danger and any entrepreneurial activity has a risky nature. Richard Cantillon, who coined the term «entrepreneurship», believed that the function of entrepreneurship is to act in uncertainty, to find in it the source of satisfaction of their material needs, and the entrepreneur is an individual operating under conditions of risk and uncertainty [20].

The risk concept is directly related to the uncertainty, unpredictability of life and activity, which are the consequence of stochastic emergence, interaction of environmental factors and internal elements, insufficient initial information or limited access to it.

Uncertainty is an integral part of life and any economic activity, especially acute it is for the market business environment. The reasons for the uncertainty are the impossibility of absolute knowledge about the future, which will be determined by the actual course of various processes, the accidental communication of parameters and influencing factors, the non-deterministic results of their interaction and possible counteraction, which leads to the emergence of unpredictable states in the future. The consequences of such unpredictable interaction and a combination of factors, phenomena, processes, behavior of subjects on the market is the inadequacy and incompleteness of information in making business decisions, the availability of various alternatives to achieve certain goals, uncertainty in achieving the objectives and obtaining the planned results.

Uncertainty is characterized by the inability to measure in advance and fully predict the probability of the occurrence of a particular situation, a particular state. The risk also provides the ability to determine the results with a certain probability of occurrence (non-occurrence) of the relevant events and their consequences for the enterprise. Uncertainty is the ambiguity of the future, and the risk reflects the probability of occurrence of certain threats (opportunities), which are generated by this uncertainty, and lead to deviation of real results from the planned [13].

It is important to note that deviations of actual results from planned ones can have both negative (destructive) and positive (constructive) character. Risk assesses the likelihood of certain obstacles to the entrepreneur's goals and objectives or the emergence of opportunities, which can be used to improve the results of management and to learn the prospective areas of activity. In accordance with this risk can be managed, and uncertain situations need to be identified in time and adequately respond to them.

According to the conducted studies, let's believe that risk should be understood as the probability (possibility) of an uncertain outcome (failure (non-occurrence of expected events) or success) as a result of making appropriate decisions (selected from possible alternative options) and/or the impact of random events, factors, circumstances.

It is clear that the complete elimination of uncertainty and risks is desirable, but an impossible task for entrepreneurs. On the other hand, it is risky situations that can become a source of winning competitive advantages for the enterprise. Therefore, it is important to learn how to make decisions in conditions of uncertainty and risk. 
Effective risk management can become an effective tool in the modern competitive struggle and a source of enterprise development provided that a reliable risk management system for all management processes and at all levels of management is developed and implemented.

Risk management involves selection and implementation of a set of methods, techniques, tools for identifying, analyzing and assessing risks with the appropriate development of a set of actions and activities to regulate activities in accordance with identified threats and opportunities for the enterprise.

According to the well-known in science axiom about the potential danger of any activity, thereby to achieve zero risk (or absolute safety) is impossible, therefore they say about the advisability of achieving a minimum (or socially acceptable) risk. However, reinsurance (the risk is reduced to zero) and adventurism (the greatest possible risk) are negative. So, reinsurance can lead to an underestimated effect, adventurism - to the failure to receive a planned result, caused by excessive risk. An optimal solution is required, which must contain a calculated risk. Justified risk is almost always useful. It increases the effectiveness of any activity [10].

So, when managing risks, the corresponding actions should be directed not to minimization but to optimizing the acceptable risks and balancing the stability of the business with the level of the riskiness of the situation, as they are also a source of new opportunities that create the prerequisites for the company's development by mastering new growth directions and searching for non-traditional sources of problem solution.

Risk management should be systematic, continuous, focused, systematic, aimed at achieving stability and long-term development of the enterprise, ensuring its competitiveness in the global market. An important task in the enterprise's risk management system under current conditions should be the timely identification of possible threats (opportunities) in a little-anticipated global business environment and the rapid adequate response of the management system to possible changes. This task is complicated by the high rates of change in the modern business environment and by information and time constraints in making appropriate decisions. An effective tool in solving this problem can be formation of a perspective-oriented system of enterprise risk management, based on the principles of anticipatory management.

Anticipatory management is aimed at developing a set of management measures to address a potential problem before its actual occurrence. The concept of anticipatory management is based on the fact that any potential event is characterized by a certain period of its development from weak to strong signals that inform about the occurrence of the phenomenon. Weak signals are information messages of a quantitative and qualitative nature, indicating initial changes in trends in the development of potential phenomena or the emergence of new trends in the environment of the functioning of the organization. Correctly identified and duly processed signals form the basis for development and adoption of preventive management decisions to anticipate the onset of potential phenomena of the internal and external environment of the enterprise [24].

The rationale for choosing this approach to risk management in modern conditions is due to the fact that the anticipatory management is aimed at early identification of potential risks in the early stages of their occurrence with the aim of adopting appropriate preventive management measures. In addition, this approach to risk management reduces time constraints on the adoption of well-founded management decisions and forms the basis for informing managers on the implementation of identified opportunities and eliminating potential threats in the operation of the enterprise.

In general, the system of anticipatory enterprise risk management under uncertainty conditions should include a set of interrelated stages (Fig. 1):

1. Selection of risk management strategy in accordance with the basic strategy of the enterprise.

2. Integrated monitoring of internal and external environment of the enterprise management.

3. Identification of weak signals of potential events, events, states that may affect the achievement of tactical and strategic objectives of the activity.

4. Rating of weak signals.

5. Forecasting the development of potential events and evaluating the flow of strong signals to the operation of the enterprise.

6. Choosing a method for managing potential risks.

7. Development of a set of preventive measures to prevent losses and use of potential opportunities.

8. Monitoring and control over the effectiveness of risk management, comparing real results with planned ones.

9. Adjustment of the risk management system in the enterprise.

The choice of a risk management strategy is an important and responsible step. The chosen strategy should be coordinated with the basic strategy of the enterprise activity taking into account the market conditions, features of activity and financial condition of the enterprise.

Complex monitoring of internal and external environment of the enterprise management is carried out with the purpose of qualitative recognition and identification of weak signals of potential phenomena. During monitoring it is necessary to take into account that weak signals contain information only about the possibility of occurrence of potential changes in operating conditions and the sources of their occurrence, and therefore they need further processing and interpretation in order to form a complete vision of the future situation [21, 25].

Identification involves the identification and detailed description of risk signals in the early stages of occurrence, which can accompany the activities of the enterprise, affecting the achievement of certain goals. An important task at this stage should be the identification of sources of real and potential risks, specific risks and the results of their mutual influence.

The specifics of anticipatory management intensifies the importance of the input information resource as a source of data on weak signals of potential opportunities and threats to the functioning environment and requires the formation of a characteristic information base that can indicate early signs of possible events, provide a sufficient data set for predicting their development, making informed management decisions, etc. The information resource can serve as a valuable source for increasing competitiveness, investment attractiveness, or using other prospects for operating conditions, as well as to avoid threats to the activities of enterprises, etc. [26]. 


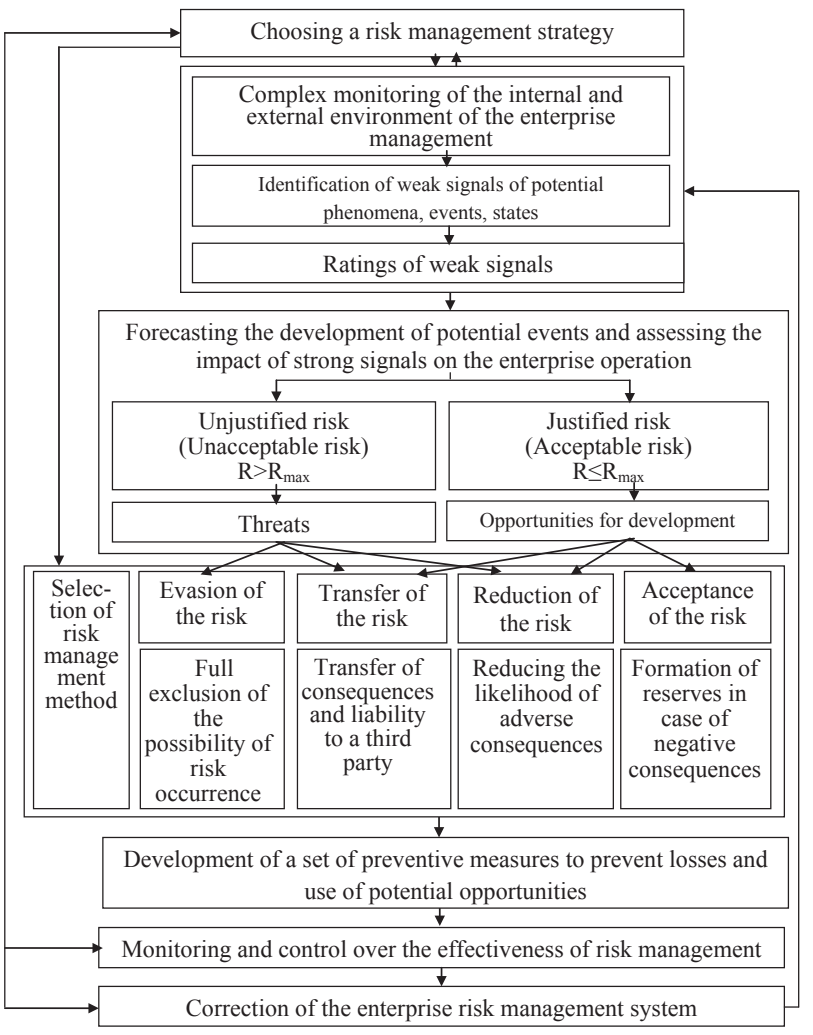

Fig. 1. Comprehensive approach to anticipatory enterprise risk management

The risk identification procedure should be a continuous process that will accompany all subsequent stages of the enterprise risk management system.

Since the identified signals can be many, then based on the results of the identification it is expedient to conduct their ratings, having received a picture of the priority of attention regarding potential threats or favorable opportunities for the development of the enterprise.

Forecasting the development of weak signals provides a logical and reasonable formulation based on the characteristics of a weak signal of all alternative options for their development to strong signals, report the occurrence of an opportunity or a threat in the environment of the operation of the enterprise. Based on established strong signals, clearly indicate the occurrence of a specific event, determine all the opportunities, threats or conditions of the enterprise [26].

Analysis of strong signals (risks or opportunities) involves determining their complexity, possible terms of materialization and the severity of possible negative consequences. An important task is determination of likelihood of onset of active risks.

Identification and analysis of weak signals can be carried out using expert assessment methods, involving specialists individually and for working in groups. The expediency of using expert methods is justified by the fact that potential events are difficult to formalize, and these methods of analysis are quite convenient in conditions of incomplete provision of information or limited access to it. Estimates of the influence of identified strong signals on the enterprise are advisable to be carried out by means of simulation modeling, which allows to determine the impact of various changes on the efficiency of the enterprise.

It is worth noting that when investigating the impact of potential risks on the operation of an enterprise, it is advisable to apply an integrated approach: the assessment is carried out as quantitatively, such qualitatively. The use of several research methods allows increasing the level of objectivity and accuracy of the analysis and forecasts made.

An important point in the risk management system is the choice of criteria for their optimization. In our opinion, the main criterion in choosing a strategy and methods for risk management is the level of acceptable (the most acceptable) risk $\left(R_{\max }\right)$, which will be determined by the established limits on spent resources for risk management, time for preventive risks, as well as the maximum acceptable level of received (lost) profit.

The level of the acceptable risk $\left(R \leq R_{\max }\right)$ determines the risk acceptability boundary, which the enterprise must determine independently, taking into account certain objectives. Unacceptable risks $\left(R>R_{\max }\right)$ are unreasonable and have mostly negative forecasts from the implementation of management decisions. Acceptable risks are justified and permissible for obtaining maximum benefit from the implementation of the adopted risky decision (negative forecasts do not exceed the permissible level). To be successful and develop, it is necessary to be able to take risks and manage them. An important place in the risk management system is the choice of the method of managing them that is adequate to the changes in the management environment.

In modern conditions, four main groups of methods of risk management have found practical application [13-15, 20]:

1. Evasion of the risk involves the complete exclusion of the possibility of materializing the risk (failure to take risky actions, avoid the influence of negative events, the rejection of unreliable contacts, etc.). This way of influencing risks is the simplest and most common in the practice of management, but it does not allow to maximize the profit, or it is a refusal of profit in general.

2. The transfer of the risk involves the transfer of the consequences of risk materialization and liability to a third party (risk outsourcing, provision of guarantees, insurance, hedging of risks, etc.).

3. Reduction of the risk - reducing the likelihood of materialization and the negative consequences from the onset of potential events (reducing the amount of losses, reducing the frequency of negative consequences, differentiating risks, etc.).

4. Acceptance of the risk provides for the formation of reserves in the event of negative consequences. It is possible to absorb risks (recognition of losses and the refusal of their insurance with allowable amounts of potential losses), limiting (determining the maximum allowable amounts of losses). This group of methods refers to preventive risk management, but it also requires a complex procedure for assessing and forecasting the development of future events.

In practice, a comprehensive approach to the application of various risk management methods is advisable, it allows to maximize the effect of their practical implementation, minimizing the costs of performing tasks, and managing risks in particular.

It is impossible to imagine any management system without a clear control that allows to identify in time the deviations from the planned goals and adjust the activities of the company in the appropriate direction. Therefore, the important steps in the developed approach to risk management are the so-called maintenance (monitoring and control) and the corresponding adjustments in the risk management system, the activities of the enterprise as a whole. Monitoring and control procedures provide for the collection and analysis of information on the performance 
of implemented risk management activities, assessing the effectiveness of relevant actions, identifying new changes in the environment and making appropriate adjustments to the enterprise risk management system.

It is worth noting that the important point in the risk management system is provision of feedback between the individual stages of risk management to ensure the clarity, focus and consistency of all management processes.

In conditions of an aggressive business environment, the success of the activity and the growth prospects of a modern enterprise depend on the chosen approach to managing risks. An effective system of preventive risk management can become not only an instrument for preventing negative consequences, but also a catalyst for competitive growth under uncertainty conditions.

\section{SWOT analysis of research results}

Strengths. The strength of research is that the proposed approach makes it possible to reduce the level of uncertainty in the current business environment, maximize the time to prepare the enterprise for potential events and make informed management decisions aimed at solving a potential problem before its actual occurrence, allows time to identify and take advantage of promising opportunities for enterprise development.

Weaknesses. The weak side is that the practical application of preventive approach to management requires significant labor and time costs for identifying weak signals, processing collected information and forecasting appropriate development scenarios. The lack of reliable information in an uncertain business environment is problematic.

Opportunities. Opportunities for further research are the need to improve the methodological support of this approach and the feasibility of its practical testing at domestic enterprises.

Threats. Threats to the research results are a high level of uncertainty in the management environment, the presence of many different weak signals from the external environment, and even more scenarios for their future development that does not provide full protection against threats and an unconditional possibility of timely response to changes in the external environment.

\section{Conclusions}

1. The cause-effect relationships between risk and uncertainty are analyzed. It is shown that in practice it is important to distinguish between risk and uncertainty. The root cause of the risk is uncertainty. Uncertainty is the ambiguity of the future and the risk is the probability of occurrence of certain risks (opportunities) that are generated by this uncertainty, and lead to a deviation of actual results from planned.

2. The main principles of risk management in modern conditions are disclosed. In risk management related activities should be directed not to minimize, and to optimize the risk tolerance and respect for the balance between the stability of the business and the riskiness level of the situation, because they are also the source of new opportunities that create preconditions for development through the development of new growth areas and finding unconventional sources of problem solution. Risk management should be systematic, continuous, focused, aimed at achieving stability and long-term development of the enterprise, ensuring its competitiveness in the global market.

3. The main principles of anticipatory management are described, which is aimed at developing a set of management measures to address a potential problem before its actual occurrence. Any potential event is characterized by a certain period of its development from weak to strong signals, informing about the occurrence of the phenomenon. Correctly identified and duly processed signals form the basis for development and adoption of preventive management decisions to anticipate the onset of potential phenomena of the internal and external environment of the enterprise.

4. An integrated approach to the enterprise's risk management under uncertainty conditions is developed, which is a sufficiently effective tool for ensuring the effectiveness of risk management, reducing the level of uncertainty in the current business environment, and maximizing the time to prepare the enterprise for potential events. This approach allows to maximize the effect of interaction between risk management and the enterprise's management environment due to early identification of potential events, forecasting their future development and making appropriate preventive measures to minimize the impact of threats and use opportunities for enterprise development. The choice of such approach in modern conditions is justified by the need to identify risks in the early stages of their emergence with a view to their effective management.

\section{References}

1. Semenova, K. D. Systema upravlinnia ryzykamy pidpryiemstva [Text] / K. D. Semenova, K. I. Tarasova // Materialy chetvertoi mizhnarodnoi naukovo-praktychnoi konferentsii «Ekonomika pidpryiemstva: suchasni problemy teorii ta praktyky». - Odesa: Atlant, 2015. - P. 203-205.

2. Marshall, A. Principles of Economics [Electronic resource] / A. Marshall. - London: Macmillan and Co., Ltd, 1920. - Ed. 8. Available at: \www/URL: http://www.econlib.org/library/Marshall/marP.html

3. Knight, F. Risk, Uncertainty and Profit [Electronic resource] / F. Knight. - Boston, MA: Hart, Schaffner \& Marx; Houghton Mifflin Co., 1921. - Available at: \www/URL: http://www. econlib.org/library/Knight/knRUP1.html

4. Mill, J. Elements of Political Economy [Electronic resource] / J. Mill. - London: Henry G. Bohn, 1844. - Ed. 3. - Available at: \www/URL: http://www.econlib.org/library/MillJames/ mljElm.html

5. Smith, A. An Inquiry into the Nature and Causes of the Wealth of Nations [Electronic resource] / A. Smith. - London: Methuen \& Co., Ltd, 1904. - Ed. 5. - Available at: \www/ URL: http://www.econlib.org/library/Smith/smWN.html

6. Keynes, J. M. The General Theory of Employment, Interest, and Money [Text] / J. M. Keynes. - Stellar Classics, 2016. - 168 p.

7. Schumpeter, J. A. The Theory of Economic Development [Text] J. A. Schumpeter. - Oxford University Press, 1962. - 255 p.

8. Markowits, H. M. Portfolio Selection [Text] / H. M. Markowits // Journal of Finance. - 1952. - No. 1. - P. 71-91.

9. Koroliuk, T. M. Istorychnyi henezys poniattia «ryzyk»: oblikovoekonomichnyi aspekt [Electronic resource] / T. M. Koroliuk. 2011. - Available at: \www/URL: http://www.nbuv.gov.ua/ old_jrn/Soc_Gum/Vlca_ekon/2011_36/43.pdf

10. Vdovichenko, O. V. Minimizatsiia neopravdannogo riska [Electronic resource] / O. V. Vdovichenko. - 2009. - Available at: \www/URL: http://scienceandeducation.pdpu.edu.ua/journals/2009/NiO_5_2009/1_razdel/vdovigh.htm

11. Sukhanova, N. Risks and threats in enterprise management in crisis situations: similarities and differences [Electronic resource] / N. Sukhanova // Efektyvna ekonomika. - 2011. No. 12. - Available at: \www/URL: http://www.economy.nayka. com.ua/?op $=1 \& z=2544$

12. Rudnichenko, E. Threats, risks, dangers: nature and relationship with the system of enterprise economic security [Text] / 
E. Rudnichenko // Ekonomika. Menedzhment. Pidpryiemnytstvo. - 2013. - Vol. 25, No. 1. - P. 188-195.

13. Vishniakov, Ya. D. Obshchaia teoriia riskov [Text]: Handbook / Ya. D. Vishniakov, N. N. Radaev, K. A. Kirsanov. - Moscow: Akademiia, 2008. - 368 p.

14. Balabanov, I. T. Risk-menedzhment [Text] / I. T. Balabanov. Moscow: Finansy i statistika, 1996. - 192 p.

15. Verbitska, I. I. Risk management as a modern risk management system of enterprise structures [Text] / I. I. Verbitska // Stalyi rozvytok ekonomiky. - 2013. - No. 5. - P. 282-291.

16. Lopatovskyi, V. H. Otsinka neobkhidnosti vykorystannia protsesu upravlinnia ryzykamy na pidpryiemstvi [Text] / V. H. Lopatovskyi // Herald of Khmelnytskyi national university. Economic Sciences. - 2008. - Vol. 6, No. 1. - P. 105-108.

17. Shpandaruk, V. O. Vdoskonalennia upravlinnia ryzykamy pidpryiemstv na zasadakh realizatsii preventyvnykh zakhodiv [Text] V. O. Shpandaruk // Herald of Khmelnytskyi National University Economic Sciences. - 2010. - Vol. 3, No. 1. - P. 241-244.

18. Starostina, A. O. Ryzyk-menedzhment: teoriia ta praktyka [Text] A. O. Starostina, V. A. Kravchenko. - Kyiv: Kondor, 2009. - 200 p.

19. Mostenska, T. Risk management as a management tool, economic risks enterprise [Text] / T. Mostenska, N. Skopenko / Visnyk of Zaporizhzhya National University. Economic Sciences. - 2010. - No. 3 (7). - P. 77-85.

20. Tebekin, A. V. Metody priniatiia upravlencheskih reshenii [Text] Handbook / A. V. Tebekin. - Moscow: Yurait, 2015. - 572 p.

21. Rudenskii, R. A. Antisipativnoe upravlenie slozhnymi ekonomicheskimi sistemami: modeli, metody, instrumenty [Text]: Monograph / R. A. Rudenskii; ed. by Yu. G. Lysenko. - Donetsk: Yugo-Vostok, 2009. - 257 p.

22. Ashley, W. C. Anticipatory Management: Tools for Better Decision Making [Text] / W. C. Ashley, J. L. Morrison // The Futurist. - 1997. - Vol. 31, No. 5. - P. 47-50

23. Harper, S. C. Anticipatory management can not be compromised [Electronic resource] / S. C. Harper, D. J. Glew // Industrial Engineer. - 2008. - P. 34. - Available at: \www/ URL: https://www.entrepreneur.com

24. Melnyk, O. G. Anticipatory enterprise management based on weak signals [Text] / O. G. Melnyk, M. Y. Adamiv // Actual Problems of Economiics. - 2013. - No. 1 (139). - P. 32-41.
25. Kuzmin, O. Y. Method of Prospective Diagnosis of Weak Signals of Potential Phenomena by Types of Company Activity [Text] O. Y. Kuzmin, M. Y. Adamiv // Business Inform. - 2013. No. 2. - P. 69-74.

26. Kuzmin, O. Ye. Antysypatyvne upravlinnia mashynobudivnymy pidpryiemstvamy na zasadakh slabkykh syhnaliv [Text]: Monograph / O. Ye. Kuzmin, L. H. Lipych, O. H. Melnyk et al. Lutsk: Vezha-Druk, 2014. - 224 p.

\section{РАЗРАБОТКА ПОДХОДА К АНТИСИПАТИВНОМУ УПРАВЛЕНИЮ РИСКАМИ ПРЕДПРИЯТИЯ В УСЛОВИЯХ НЕОПРЕДЕЛЕННОСТИ}

Предложен комплексный подход к антисипативному управлению рисками предприятия в условиях неопределенности. Подход основан на ранней диагностике слабых сигналов потенциальных возможностей и угроз среды функционирования предприятия, что позволяет прогнозировать их будущее развитие и принимать соответствующие превентивные меры по минимизации влияния рисков и использования возможностей для перспективного развития предприятия.

Ключевъе слова: антисипативное управление рисками, идентификация слабых сигналов, превентивные меры, оптимизация допустимых рисков.

Lesko Alexandr, PhD, Associate Professor, Professor of the Depart ment of Economics of Enterprise and Production Management, Vinnytsia National Technical University, Ukraine, e-mail: epvm@ukr.net, ORCID: http://orcid.org/0000-0002-1499-2632

Prychepa Iryna, PhD, Associate Professor, Department of Enterprise Economics and Production Management, Vinnytsia National Technical University, Ukraine, e-mail: prychepa.iryna@gmail.com, ORCID: http://orcid.org/0000-0002-0805-2732

Lesko Tatyana, Department of Economics Enterprise and Production Management, Vinnytsia National Technical University, Ukraine, e-mail:08tanya101997@gmail.com,ORCID: http://orcid.org/00000003-3220-2822

\section{Striy L., \\ Orlov V., \\ Zakharchenko L., \\ Golubev A., \\ Bogatyreva L.}

\section{ENTERPRISES OF TELECOMMUNICATIONS IN UKRAINE: RESEARCH OF THE PRESENT STATE AND DIRECTIONS OF DEVELOPMENT}

Викладено результати комплексного дослідження економічної діяльності підприємств телекомунікацій України в 2015-2016 роках і напрямків ї̈ розвитку. Виконано оцінку стану конкурентного середовища на ринках телекомунікаційних послуг. Встановлено, що виникла сприятлива тенденція підвищення результативності діяльності підприємств. Зроблено висновок, що підприємства телекомунікацій можуть повністю забезпечувати виконання комунікативних функцій в глобальній інфокомунікаційній сфері, яка формується.

Ключові слова: інфокомунікащї, кіберпростір, конвергенщія технологій, комунікації, конкурентне середовище, підприємства телекомунікащії.

\section{Introduction}

Enterprises of telecommunications in Ukraine, as well as world telecommunications, experience transformations related to the evolving processes of convergence of information and communication technologies, as well as integration into the cyberspace of the Internet. Infocommunication services markets are being formed, at which telecommunications enterprises begin to perform, mainly, communicative functions for the transfer of digital information products from producers to consumer terminals. Many enterprises also seek to produce (or broadcast) various digital products (television channels, 